\title{
An Introduction to Teaching English Compound Nouns in EFL
}

E.M. Zakhtser

Financial University, Moscow, Russia https://orcid.org/0000-0002-9044-4881

\begin{abstract}
Native speakers of English accept and use noun + noun compound nouns so readily and naturally, that they fail to notice the grammatical incongruity of using one noun to describe another. Learners of English whose native languages have a stricter grammatical basis than English find these constructions not merely difficult to use - but puzzling, and apparently 'wrong'. This paper aims to correct this position by providing extensive illustrations from everyday English speech to describe how commonplace, such constructions are (and how, in many cases, there is no alternative to using them) - alongside a methodological guide to forming and using compound nouns, with particular reference to their use in the banking, financial and insurance industries in which many learners hope to make their careers. Teaching this topic is currently poorly supported in standard teaching materials - even excellent, and widely-used EFL textbooks make no mention at all of this very commonly-used structure. Compound nouns stand in dire need of an academic pedigree to support them. The paper reviews the two primary kinds of compound nouns found in English (Attributive, and Contextual), with working examples illustrating their varying usages.

Keywords: English language; compound noun; formation and categories of compound nouns; rules and examples
\end{abstract}

For citation: Zakhtser E.M. An Introduction to teaching English compound nouns in EFL. Gumanitarnye Nauki. Vestnik Finasovogo Universiteta = Humanities and Social Sciences. Bulletin of the Financial University. 2019;9(6):125-132. DOI: 10.26794/2226-7867-2019-9-6-125-132

ОРИГИНАЛЬНАЯ СТАТЬЯ

\section{Обучение английскому как иностранному. Составные существительные}

\author{
E.M. Захцер \\ Финансовый университет, Москва, Россия \\ https://orcid.org/0000-0002-9044-4881
}

\begin{abstract}
АННОТАЦИЯ
Носители английского языка используют составные существительные (существительное + существительное) настолько легко и естественно, что не замечают грамматического несоответствия использования одного существительного для описания другого. Студентов, изучающих английский язык как иностранный, подобные конструкции приводят в замешательство. В данной статье приводятся примеры из повседневной английской речи, помогающие осознать обычность таких конструкций (во многих случаях им просто нет альтернатив). В статье рассматриваются два основных типа составных существительных, встречающихся в английском языке (атрибутивный и контекстуальный), а также предлагается методологическое руководство по образованию и использованию составных существительных в банковской, финансовой и страховой отраслях.

Ключевые слова: английский язык; составное существительное; образование составных существительных; категории составных существительных; примеры составных существительных
\end{abstract}

Для цитирования: Захцер Е.М. Обучение английскому как иностранному. Составные существительные. Гуманитарные науки. Вестник Финансового университета. 2019;9(6):125-132. DOI: 10.26794/2226-7867-2019-9-6-125-132 


\section{COMPOUND NOUNS -}

\section{AN INTRODUCTION TO THE GUIDELINES (AND WHY WE NEED GUIDELINES AT ALL)}

\section{The root of the problem - English lacks sufficient adjectival forms}

To name the Moscow rail station from which trains go to Kyiv, Russians use the name 'Kievsky Vokzal' (literally, 'the Kyiv-ish Station'). But this sounds wrong to English ears, and so guidebooks call it 'Kyiv Station' in English. Yet to Russian-speakers, that would mean the central railway station in the city of Kyiv. What may be 'clear enough' to anglophones jars with speakers of languages based on stricter grammar?

Compound nouns (noun + noun) are becoming more popular in English - in all genres of writing. Nowadays they increasingly replace formerly-used noun+adjective combinations - particularly where they are used to express a 'compound concept', whose meaning is incomplete (or even wholly different) if one part of the compound noun is missing. Native speakers of English are so accustomed to their use that they frequently close their eyes to the grammatical 'wrongness' of using pairs of nouns like this. They cause immense frustration - not to say disbelief - to foreign learners of English, whose own languages conventionally use adjectives as noun-describers instead.

Whatever their rights or wrongs, compound noun + noun pairs are core-use elements in modern everyday English. Consider, for example, the compound noun 'police car'. Neither noun, on its own, can give the meaning. Nor is there any officially-acceptable single-noun alternative to describe something straightforward - something that we see almost every day. 'Police car' does not supersede any previous noun+adjective combinations. The pace of change of modern life creates constant, ongoing demand for new terms to describe objects, concepts, inventions and ideas. Some compound nouns enter dictionaries, thesauruses, glossaries and professional literature as what are often called 'phrases' - and in specific official contexts (financial, legal, regulatory, governmental) it could be said that 'tax refund', 'speed limit', 'government policy', 'speed bump', or 'credit limit' have gone beyond simply 'naming things', and have become established concepts of their own. They can be reliably found in English-English dictionaries. They serve their users well and provide a 'standardised' translation of concepts which are widely understood internationally - although they add enormously to the corpus of vocabulary which is expected to be at the disposal of English speakers. If only we could reach for our dictionaries when we meet a new compound noun, things would be well (although, perhaps, a little slow).

Yet things are not so simple - because such 'wellestablished', or standardised compound nouns, as found in dictionaries, account for only a fraction of those which the students of English Language may encounter even today. There is no complete or even partial list of them to be found at any source. The reason is apparent immediately from their alternative designation as 'adjectival' nouns - any attempt to make such a list would mean not only listing every English noun, but also multiplying each entry by several qualifiers. Available textbooks have understandably panicked in the face of such vast numbers of possible results - and instead opted for giving a few examples, and commenting that there could be 'many more'. Yet our students need more practical and complete assistance in the relatively simple task of recognising them and translating them into other languages - to say nothing of the much more difficult task of constructing their examples.

The objective of this paper is to highlight the GUIDELINES by which English native speakers create their compound nouns - for they certainly do create them, and relish the creative process involved. Closing our eyes to an issue as widespread in English as compound nouns isn't an option. Nor is memorising lists of prominent examples. By classifying the parameters which define successful models, our students can proceed confidently towards the (advanced) skill of creating the compound nouns they need in their professional work.

In the course of developing these guidelines, the author has extrapolated from material initially presented as helpful comments and answers on the blog written by the pre-eminent English lexicographer and linguistician Professor David Crystal - and expanded principles established in isolated cases into a more comprehensive system of guidelines aimed at making this material accessible to non-native learners of English.

\section{COMMON TYPES OF COMPOUND NOUNS IN ENGLISH - AND WHY THEY ARE USED SO OFTEN}

The creative formation of compound nouns in English has a long history and is a trait that English shares with other languages of the Germanic group 
Compound nouns. combinations

\begin{tabular}{|c|c|}
\hline $\begin{array}{l}\text { word-form combination } \\
\text { (either separate, hyphenated, or joined) }\end{array}$ & example(s) \\
\hline noun + noun & $\begin{array}{c}\text { toothpaste/tooth paste } \\
\text { a police car } \\
\text { an opera singer } \\
\text { chocolate biscuits }\end{array}$ \\
\hline adjective + noun & $\begin{array}{c}\text { British Rail (the UK national railways monopoly } \\
\text { corporation) }\end{array}$ \\
\hline verb (gerund) + noun & training centre \\
\hline preposition + noun & Underground (the London 'metro' suburban rail system) \\
\hline noun + verb (gerund) & bed-wetting/bedwetting \\
\hline noun + preposition & hanger-on (an unwanted/uninvited friend) \\
\hline
\end{tabular}

(particularly German and Dutch). Just as in German and Dutch, the formation of compound nouns usually arises out of need - from the lack of an exact word or term to express a particular concept or nuance. A new concept stems from the juxtaposition of the words in the compound noun - one which has a no better available expression in a singleword term. Linguisticians often list several possible such combinations - and although many of these are rather mundane ('noun + adjective'), we should probably list them, for the sake of completeness. As indicated in Table 1, we have focussed primarily on those where an exceptional meaning arises from the combination.

Although we can accept this list of types - which is in general circulation in English textbooks - the genre of particular interest is the noun + noun group, for several reasons. The primary one is that in all the other groups, the words function according to their usual type, so there is nothing 'special' that is worthy of our consideration. But the secondary reason is in the noun + noun group, one of the nouns has fallen into use as an 'unofficial' adjective. Why has this happened? Aren't there any adequate adjectives which might have been - more correctly? - Used instead? And most crucially, what rules or conventions have been applied that makes the (grammatically incorrect) version of 'chocolate biscuits' preferable to such 'correct' possibilities as 'chocolatey biscuits', 'chocolate-flavoured biscuits', 'biscuits with chocolate', 'chocolate-covered biscuits', or other (grammatically correct) versions?

The extent of different versions which might be used in such cases - and the rarely-documented 'rules' which lie behind such names - necessitate confining the attention of students to the noun + noun group alone - since the formation of the other types conforms to the usual rules for the format and placement of adjectives, prepositions and other grammatical forms. Yet lest readers should imagine that an academic paper about 'chocolate biscuits' - and similar cases - is something of a charmingly irrelevant sideshow, we must remember that legal matters - with some results leading to the payment of millions of euros in fines and compensation - have been fought and won (or lost) over whether a 'McVitie's Jaffa Cake', is a 'cake'; a 'Jaffa Cake'; a 'biscuit'; or a 'chocolate biscuit'; under the definitions stipulated in European Union legislation ${ }^{1}$ :

The product's name was regarded as a minor consideration.

The ingredients were regarded as similar to those of a cake, producing a thin cake-like batter rather than the thick dough of a biscuit.

${ }^{1}$ United Kingdom VAT \& Duties Tribunals Decisions - Torq Ltd v UK Revenue and Customs Agency. 2005. 
The product's texture was regarded as being that of a sponge cake.

The product hardens when stale, in the manner of a cake.

A substantial part of the Jaffa cake, in terms of bulk and texture, is sponge.

In size, the Jaffa cake is more like a biscuit than a cake.

The product was generally displayed for sale alongside other biscuits, rather than with cakes.

The product is presented as a snack and eaten with the fingers, like a biscuit, rather than with a fork as a cake might be. The tribunal also considered that children would eat them in "a few mouthfuls", in the manner of a sweet.

The court found in favour of McVitie's and ruled that the product should be considered a cake, meaning that VAT is not paid on Jaffa Cakes in the United Kingdom.

It makes the study and mastery of the complex subject of compound nouns of direct and vital relevance to students aiming to find their jobs in finances, accounting, law, or management.

\section{RULES GOVERNING ATTRIBUTIVE NOUNS ('NOUNS WHICH FUNCTION AS ADJECTIVES')}

The critical, semantic and syntactical distinction of Attributive Nouns - nouns which function as adjectives - is their function. Despite their linguistic form as nouns, they fulfil the function of adjectives - and thus they behave as adjectives in many ways - of which the most noticeable are that:

They do not have number, article or case agreement with the noun they qualify (i.e. they follow the typical 'agreement' pattern for English adjectives).

They are placed before the noun they qualify.

Where a composite number of descriptors (additional attributive nouns, adjectives, gerunds, or other parts of speech) are used as noun attributes, the conventional hierarchical order of descriptors is re-ordered to place the compound noun (the attributive noun) in prime position (the final position before the primary active noun).

Let us look at working examples, as indicated in Table 2, of Rules 1, 2, and 3 above, using a compound noun grouping in everyday use - 'police car'. (This example is given since its meaning is instantly understandable, nor there is any singleword alternative in use).

\section{COMMON USES OF ATTRIBUTIVE NOUNS IN NOUN + NOUN EXAMPLES}

The two most frequent uses of Attributive Nouns are when describing either the ownership or the function of the object/service/concept given as the primary noun. These usages (unlike Contextual Nouns) often have legal, professional, or fiscal implications. (Very often, ownership and function overlap. For example, 'police car' is not only a car owned by the police but it also has characteristics (paintwork livery, blue flashing lights, sirens) not found in conventional cars, which have been retro-fitted after manufacture to enable/improve its functional suitability for police work.)

By analogy, the attributive noun 'police' can be applied to other items or services owned, operated, or provided by the police, e.g. police officer, police forensic experts, police station, police cell, police uniform (and all elements of it - police hat, police boots, etc.), police gun, police handcuffs (and many, many others).

In all of these examples, 'police' has effectively been used as an adjective to denote function - in the place of any other suitable adjective, or genitive case. Similar sets of attributive nouns can be compiled for other governmental services and institutional bodies: army officer, army vehicle, army barracks, school teacher, school book, school building, hospital bed, etc.

\section{ASSOCIATIVE INTERPRETATIONS}

A further category of noun + noun constructions arises from associative interpretations. (These have been extensively catalogued by G.V. Matchenko [4].) This use of compound nouns arises primarily with people (or sometimes other nouns) whose primary value or interest to the reader arises from one narrowly-defined personality trait, habit, professional activity, or idiosyncrasy. Matchenko rightly highlights the possible unfairness of such stigmatising labels as, for example, 'boat people' (people who arrive on a boat), 'water assistant' (delivery staff who bring large containers of drinking water to offices) or 'chicken man' (seller of chicken meat at a market stall).

However, the continuing evolution of these terms can go in unexpected, and socially extreme directions. Matchenko's 'boat people' (which he had codified in 2012 as being 'the crew or passenger-list of a ship or boat') had mutated to a single meaning of 'refugees who flee by boat', and with further-mutated meanings leading towards 'illegal immigrant', 'bogus 


\section{Working Examples}

\section{1) The attributive noun does not form number, article or case agreement with the primary noun} FOR ARTICLES:

- 'The crowd quickly scattered when a police car arrived'.

the selection of a relevant article is made based on the primary (second) noun in the compound noun group. Normal rules for selection of articles apply. It is of particular importance, since many attributive nouns are (perhaps not coincidentally) uncountable, and would therefore not require articles in any case (i.e. no article is used). 'Police' could be considered uncountable in some semantic contexts. Compare what happens if the transport used by the police is not important in the example:

'The crowd quickly scattered when police arrived'. (No article is needed if we are considering only their arrival. In some contexts, their arrival as the representatives of the state might matter require a definite article, with or without their car: 'The crowd quickly scattered when the police arrived'.

FOR NUMBERS:

'The crowd quickly scattered when police cars arrived.'

- Only cars are pluralised - as usually with English adjectives, there is no available plural form for 'police' in any case, and even if there were, none could be used in this example. Just to make the point clear, polices cars would be entirely wrong. Note also that no article is used - because of the usual 'no-article' rule for plural nouns.

\section{FOR CASES:}

'The crowd quickly scattered when they heard the police car's siren.

We often forget that although English 'lost' its complex case structure (somewhere in the $13^{\text {th }}$ century), the genitive case continues to exist in English, and is expressed using an apostrophe. Just as with non-agreement in numerical cases, only the primary noun forms a genitive case here, and the attributive noun does not take a genitive case. (It would be wrong to attempt to form one for the attributive noun - the police's car's siren would be a severe mistake. But see the explanation further below about non-attributable alternative forms to compound nouns which can be desirable for clarity in certain semantic circumstances.)

KEY INFORMATION FOR STUDENTS:

The use of relevant articles, number agreement, and case agreement make it $100 \%$ clear which of the two nouns in a compound noun is the PRIMARY noun. It is therefore of crucial importance, when using a compound noun, to decide in advance, which is the primary noun, and place it second in the compound set - to avoid possible confusions of meaning.

Occasionally it could be possible that reversing the position of the two nouns is permissible, BUT this is almost always done to achieve a very specific effect of meaning. One such possibility in our example is if two different groups of police arrive at the same moment - one group in vehicles, and the other on horses (British riot police often use horses, so this is not an impossible example). "The crowd scattered when the mounted police arrived, but the arrests were made by the car police who chased the suspects on foot." In this case, "car' has become the attribute of the police who arrived in vehicles.

\section{2) Attributive nouns are placed BEFORE the nouns they qualify.}

This position sounds absolutely natural and logical to native speakers, who often have not even realised that a noun has been used instead of the more 'correct' adjective they expect in that location.

In the case of the police car, the attributive 'police' has been used in the absence (in English) of a contemporary adjective derived from the word 'police'. Of course, in Russian, we would more normally write 'полицейская машина'. Students need to scan translation texts in advance for such instances and be ready to 'create' a compound noun where there is no suitable English adjective to use. (Although these examples are clearly absurd, none of the possible adjectival forms derived from 'police' are inadmissible here - 'police-ish car', 'policeman's car', etc. The use of the former term 'constabulary' in its adjectival form has now become so impossible archaic that it would only sound absurd in modern English - 'a constabulary car' has the idea of some ancient vehicle, possibly drawn by horse? A further example of mistakes which can creep into texts. If one has to resort to obscure or outdated terms to create an alternative to a compound noun, it is best not to do so at all.)

KEY INFORMATION FOR STUDENTS

In case the examples in (1) above were not already above, the positioning of the attributive noun in the preceding ('adjectival') location to the primary noun gives it a definite 'adjectival' function. 
3) Attributive nouns may require some reordering of the conventional hierarchical order of descriptors - they usually come last (but not always).

Although often not taught in any formal context, there exists an informally-applied (yet instantly recognisable) hierarchical order of descriptors which are used preceding nouns in English. Although the order is in some ways 'negotiable' (if certain characteristics are deemed of greater importance in context), the order is arranged in a scale of increasing importance (or value) - with the least important information coming first, and the most important descriptors appearing directly before the noun. Of course, very few (if any) examples would use all, or even many, of the descriptors (adjectives, attributes etc.) listed here - this list simply shows the order in which they should be placed if they are present at all.

1) subjective opinions ('fat', 'conceited', charming' etc.)

2) size ('bulky', 'thin', etc.)

3) shape ('circular,'square')

4) condition ('broken,' worn-out')

5) age ('elderly,'sprightly,' 'Medieval,'space-age')

6) colour ('red', 'blue')

7) pattern ('zig-zag','check')

8) origin ('Italian', 'solar', 'soil') - note that this group might contain attributable nouns

9) material ('wooden,' 'leather', oak) - note that this group can contain attributable nouns

10) purpose ('hunting,',domestic','police') - note that this group often contains attributable nouns

It is in the nature of attributable nouns to be among the most important of any list of descriptors. Even so, there can be multiple attributable nouns used to describe the attributes of the primary noun - and in this case the hierarchical order dictates their logical position in the 'procession' of attributes (of all syntactic kinds) which precede the noun.

In literature, authors are free to rearrange this order creatively, for their own ends. In official or technical literature, breaching this 'informal' hierarchy would require very clear and necessary justification to be considered acceptable. Examples:

"The Chief Constable complained that due to budgetary cuts, his force still owned and maintained many worn-out, blue-and-white, British-made police cars."

- The most important attribute is their purpose for police use, so the compound noun is not split, and comes as a two-word unit at the close of the list.

Even so, since the order is strictly hierarchical, there could be cases where other attributes are considered (in context) to be of greater importance than the usual position of attributive nouns at the end:

"The Chief Constable hoped that by the end of 2020, his force would introduce one hundred new, German police high-speed cars to modernise its fleet." ('High-speed police cars' would also be acceptable - but if the police had been accused of failing to catch criminals, the element of their speed might be the 'most important' element in the hierarchy.)

asylum-seeker', and more generally as 'vagrant' [3]. It is now effectively impossible to mention 'boat people' without implicitly suggesting 'illegal refugees - a heavily stigmatised term.

\section{CONTEXTUAL CLARIFICATION IN COMPOUND NOUNS}

The use of a secondary, qualitative (contextual) noun to describe a primary noun has a separate history of usage in English. This particular noun-noun version of compound nouns occurs when the field of reference of the primary noun is effectively defined by the qualitative noun, to create a cognitive multiword unit in which the resulting neologism is not only substantially differentiated in meaning from its component parts - but is furthermore capable of assuming a usage which has highly-specific legal, financial, technical or legislative meaning as in the case of the term 'boat people'.

To step aside from the emotionally-charged (and highly subjective) issues of refugees, we could instead take to the roads of our major cities - since ever-increasing user numbers provide a rich seam of new words used to describe social phenomena. 'Car space' and 'parking space' (technically a gerund + noun combination) have become not only generally-used and universally understood terms - they also comprise a technical definition of some square metres which can be rented by the hour, or even sold in perpetuity. In this sense, they have acquired a defining status in Contract Law - by which we mean that no other similar or equal terms could be substituted, without loss of legal rights. It has important implica- 
tions for students - simply 'inventing your own' phrase as a translation can lead to unexpected legal consequences.

How are these contextual clarifications formed in compound nouns? David Crystal [1] has pointed out that when the 'authority' for the field of reference comes from some official body or organisation, the English tendency for referring to such bodies in the plural is deployed in the compound noun too, e.g., an examinations committee, a prints and drawings exhibition, the heavy chemicals industry, etc.

\section{CONTEXTUAL COMPOUND NOUNS IN THE FINANCIAL SECTOR}

Yet despite the convenient generality of plural forms - which cover a wide variety of contexts when we come into the financial arena, the equally suitable use of singular forms applies, due to the admirable accuracy such field-narrowing offers: "The government will set out its tax policy for the next financial year." Alternative forms such as 'taxation policy' or 'taxes policy' are too limp and inexact in this context. It is a general (singular) approach to the formation of compound nouns with exact legal or fiscal meanings which we can see applied throughout the financial sphere, e.g., investment bank (not investments bank, investing bank), interest rate, exchange rates, job contract, market maker, wage freeze, profit warning, hedge fund, loss report, growth statistics, etc. We also find a long category related to taxation, where 'tax' is preferred to the (possible) 'taxation', e.g., tax credit, tax holiday, tax inspector, tax declaration, tax payment, tax rate, etc.

Despite being formed in the same way as Attributive Nouns, Contextual Nouns do not imply any particular legal or financial parameters. It has both advantages and drawbacks. The drawbacks are that anyone who enters into a bank loan is not protected by specific legislation regarding its terms and conditions (although in many legislations, there are, at least, some basic laws in place regarding which institutions can describe themselves as banks). Such a loan could be both good value or very bad value for the borrower - such terms are not implied by the Contextual Noun involved. The advantages are that, in the absence of possibly over-restrictive legislation regarding terminology, new vocabulary can spring into place to name new financial instruments, concepts, and methods of operation. It could be of particular value at a time when the pace of change in the financial industries is very fast - like banks, and other institutions quickly shed their high-cost overheads (banking halls, buildings, and so forth) in a rush to migrate to new areas of interaction with their clients, e.g. internet banking, mobile banking, online banking, FinTech (an abbreviation of finance technology)... and many others.

Gunchenko, Hnatenko, and Tanko [2] have commented on the importance of nominative or representative function that is a denomination of a definitive meaning, and go on to highlight the double value to publishers of such usage in headlines. They grab the reader's attention and focus readers towards relevant sections of text, and similarly, take up less space on the printed page, e.g., "CSU leader warns Merkel over eurozone bailouts" (FT, Wednesday July 4th 2012, p.4).

\section{POSSIBLE ERRORS}

\section{AND SITUATIONS TO AVOID}

Examples involving proper nouns (the personal names of people, the names of cities, countries, or continents) can seldom be used as Attributive Nouns. In the case of countries - identifying the origin of the primary noun in the sentence - such constructions are best handled with a conventional adjectival form, and this should remain capitalised in all cases, e.g. German industry, Japanese manufacturing, American cars or possibly with a genitive case (formed with apostrophe s) - France's car industry, Bulgaria's imports, etc.

The latter case demonstrates a clear example of how misunderstandings can occur. 'Bulgarian imports' means Bulgarian-made goods, which another country buys. But 'Bulgaria's imports' means the opposite - the list of foreign-made products, which Bulgaria buys from other countries.

Forming compound nouns with the names of cities is not so straightforward in English since many city names lack conventional adjectival forms. Thus in these cases, users are 'forced' to use a compound. For example, in France Paris has adjective Parisian but Reims, Niçe, Limoges have no adjective at all.

In the financial sphere, where Wall Street's eponymous fame has passed into synecdochal usage for 'any kind' of finance-industry in the United States, 'Wall Street' has become an Attributive Noun for use in related compounds, e.g. Wall Street brokers, Wall Street mentality, Wall Street profitability and so on. 
In other words, 'Wall Street' now signifies only financial activity, and the rules which would otherwise govern a place-name have been largely forgotten - the linguistic process known as synecdoche. A similar phenomenon can be seen in compounds related to the European Economic Union, e.g., Brussels officials, Brussels bureaucrats, Brussels regulations.

\section{CONCLUSIONS}

The pace of change in internationally-recognised financial vocabulary is now growing faster than traditional sources (such as the Oxford English Dictionary) can codify and record it. It is not only a reflection of the substantial technical changes sweeping through financial markets but burgeoning legislative streamlining and voluntary compliance. The fast-expanding new financial industries related to FinTech (blockchain, e-currencies, and similar innovations) are all being conducted in English - and impose an automatic requirement on users to communicate and log their transactions in English too.
Now that the Finance Ministry of the Russian Government has given its official blessing to blockchain technologies, the push towards globalisation of financial services markets - and thus the need to adopt international standards, and the (English) language which regulates these standards, is longer a question - it is a certainty. The entire 'crypto' market is delineated in terminology which has arisen 'on-the-fly' out of urgent need, and its central concepts and internationallyaccepted concepts are dominated by compound nouns which are typical of 'international English' - 'bitcoin market', 'bitcoin exchanges', 'Initial Coin Offering', 'web wallet' - the list is never-ending. As these new markets mature, stabilise, become subject to external regulators, and so forth, the likelihood of new terminology being self-developed to govern and control these markets points towards an ever-evolving new landscape for compound nouns in the financial sectors. Students who seek careers in these industries will find the study of these linguistic concepts pay off very highly.

\section{REFERENCES}

1. 1. Crystal D. On plural adjectives. In DCBLOG. 2010. URL: http://david-crystal.blogspot.com/2010/05/ on-plural-adjectives.html (accessed on 28.06.2018).

2. 2. Gunchenko Yu., Hnatenko Ya., Tanko N. Text-Forming \& Cohesion Features of English Compound Nouns - Economic Terms in Scientific-Economic Popular Texts. Science of Europe [Philological Sciences]. 2016;3(3):56-58.

3. 3. Johnson S. Six Iranian boat people posing as refugees will be deported after lying about their status to be granted asylum in Australia. Daily Mail Australia. 12.06.2017.

4. 4. Matchenko V. On the experience of experimental research of substantive compounds in the English language. In Scientific notes. Electronic scientific journal of Kursk State University. URL: http://scientificnotes.ru/.

\section{ИНФОРМАЦИЯ ОБ АВТОРЕ}

Елена Михайловна Захцер - преподаватель, Департамент языковой подготовки, Финансовый университет, Москва, Россия

zakhtser@mail.ru

\section{ABOUT THE AUTHOR}

Elena M. Zakhtser - Lecturer, Department of Language Training, Financial University, Moscow, Russia zakhtser@mail.ru

Статья поступила 13.09.2019; принята к публикации 03.10.2019.

Автор прочитала и одобрила окончательный вариант рукописи.

The article received on 13.09.2019; accepted for publication on 03.10.2019.

The author read and approved the final version of the manuscript. 